\title{
FENOMENA \\ KEHIDUPAN KETURUNAN EKS PARTAI KOMUNIS INDONESIA DI KABUPATEN BANYUWANGI TAHUN 2018
}

\author{
Mundir \\ Institut Agama Islam Negeri Jember \\ Email: mundzirrosyadi@gmail.com
}

\begin{abstract}
This type of phenomenological qualitative research intends to explore and describe the religious, social and cultural life of people descended from the former Indonesian Communist Party (PKI) in the Banyuwangi Regency. By analyzing interactive model data, the following research results are obtained. First, the religious life of the former PKI religious community is similar to those of other religions. They mostly acknowledged that the involvement of their parents and grandparents in the PKI was only due to ignorance and because of economic factors. Secondly, the social life of former PKI descendants in Banyuwangi was normal, even though there was something abnormal. While from the aspect of their work many works as teachers, farmers or private and participate in the transmigration program. Third, the cultural life of the descendants of former PKI members in the Banyuwangi Regency exists in developing the culture and arts of Banyuwangi, such as ketoprak, puppet people, ludruk, ande-ande moss, angklung, and keroncong. Art for them is an expression and freedom in conveying ideas through music and art.
\end{abstract}

\section{Keywords: Religious, Social, Cultural Life, Ex-PKI}

\begin{abstract}
Abstrak
Penelitian kualitatif jenis fenomenologi ini bermaksud untuk mengeksplor dan mendeskripsikan kehidupan agama, sosial, dan budaya masyarakat keturunan eks Partai Komunis Indonesia (PKI) di Kabupaten Banyuwangi. Dengan analisis data model interaktif, diperoleh hasil penelitian sebagai berikut. Pertama, kehidupan agama ketunran eks PKI berjalan seperti para pemeluk agama lainnya. Mereka kebanyakan mengakui bahwa keterlibatan orang tua dan nenek kakek mereka ke dalam PKI hanyalah karena faktor ketidak mengertian dan karena faktor ekonomi. Kedua, Kehidupan bersosial eks keturunan PKI di kabupaten Banyuwangi berjalan normal, sekalipun ada yang tidak normal. Sementara dari aspek pekerjaan mereka banyak bekerja sebagai guru, petani atau swasta dan mengikuti program transmigrasi.. Ketiga, Kehidupan budaya keturunan eks anggota PKI di Kabupaten Banyuwangi mereka eksis dalam mengembangkan budaya dan kesenian Banyuwangi, seperti ketoprak, wayang orang, ludruk, ande-ande lumut, angklung, dan keroncong. Seni bagi mereka adalah ekspresi dan kebebasan dalam menyampaikan ide melalui musik dan kesenian.
\end{abstract}

Kata Kunci: Kehidupan Agama, Sosial, Budaya, Eks PKI 


\section{A. Pendahuluan}

Keturunan eks Partai Komunis Indonesia (PKI) adalah warga negara Indonesia sebagaimana keturunan non PKI. Mereka adalah bangsa Indonesia. Mereka adalah manusia yang sama, yang memiliki hak hidup yang sama. Mereka memiliki hak-hak fundamental yang melekat pada kodrat kemanusiaannya, sebagai mahluk ciptaan Tuhan. Hak-hak ini bersifat universal dan berlaku di seluruh dunia. Sesuai dengan amanat UU RI No. 26 Tahun 2000, bahwa hak asasi manusia (HAM) merupakan hak yang melekat padanya sebagai makhluk Tuhan YME; bersifat universal dan kekal,, harus dijaga, dihormati, dipertahankan, dan tidak boleh ditelantarkan, dikurangi, atau bahkan diambil paksa oleh siapapun (Presiden RI, 2000:1).

Indonesia memiliki sejumlah regulasi terkait dengan HAM, misalnya: a) UU No. 5/1998, berisi tentang ratifikasi terhadap aturan anti kekejaman dan penyiksaan. b) UU No. 9/1998, berisi tentang kebebasan menyatakan pendapat. c) UU No. 11/1998, berisi tentang hak dan kewajiban buruh di Indonesia. d) UU No. 8/1999, berisikan tentang hak dan perlindungan konsumen. e) UU No. 19, 20, dan 21/1999, berisi tentang perburuhan. f) UU No. 26/1999, berisi tentang pencabutan hukum subsversi yang dianggap membatasi hak berpendapat. g) UU No. 39/1999, berisi tentang HAM. h) UU No. 40/1999, berisi tentang pers, hak dan kewajibannya. i) UU No. 26/2006, berisi tentang pengadilan terhadap pelanggar HAM. Namun, dalam beberapa situasi, terdapat sejumlahorang yang tidak mendapatkan hak-hak dasar mereka karena faktor internal dan eksternal. Faktor internal, dapat berupa sifat dendam, egoism, tidak toleran serta rendahnya kesadaran akan HAM. Dari faktor eksternal, dapat berupa lemahnya hukum, dan kesenjangan struktur sosial dan politik (Yuliarto dan Prajarto, 2005:291).

Berdasarkan data yang dihimpun Kontras (2012:22), beberapa kasus yang dialami oleh eks PKI dan keluarga mereka yaitu selain tidak dapat dipilih dalam Pemilihan Umum, pada zaman orde baru, para eks tahanan politik juga tidak dapat memperoleh KTP seumur hidup yang lazimnya diberikan pada warga negara berusia di atas 60 tahun. Bagi eks tahanan politik (tapol), mereka harus melakukan ragristrasi KTP pertiga tahun. Hal ini tertera dalam Kepmendagri No. 24 Tahun 1991. Hal ini terjadi di berbagai wilayah Indonesia termasuk Banyuwangi Jawa 
Timur, seperti: di desa Karang Asem (sekarang Yosomulyo) kecamatan Gambiran, Cluring, Tegaldlimo, Rogojampi, Singojuruh, dan lain-lain.

Sementara itu, pembunuhan massal usai G30S/PKIjustru terjadidengan target pembunuhan bukan hanya mereka yang dipandang sebagai anggota PKI, namun juga mereka yang dianggap berseberangan dan membahayakan kelompokkelompok tertentu (www.merdeka.com (online) 19-3-2018).Pembunuhan dengan sasaran orang-orang berpengaruh di masyarakat, seperti pada peristiwa Lubang Buaya Jakarta dan peristiwa di Jawa Timur menunjukkan adanya target politik tingkat tinggi dan merupakan teror mental. Timbulnya keresahan sosial sebagai akibat aksi itu merupakan pelanggaran Pasal 9 (2) UU No 39/1999 tentang Hak untuk Hidup Tentram, Aman, Damai Bahagia, Sejahtera Lahir Bathin (Nur Kholis, 2012:37).

Dari sinilah muncul pendapat yang menyatakan bawah PKI adalah gerakan yang melanggar HAM, bukan mereka yang membubarkan PKI. Namun yang menjadi persoalan sekarang adalah bukan siapa yang membunuh, siapa yang dibunuh, atau latar belakang politik di balik terjadinya pembunuhan. Persoalan serius adalah tentang status eks PKI yang dialamatkan kepada anak keturunan para anggota eks PKI. Apakah mereka begitu saja diberi status eks PKI, ataukah mereka diberi kesempatan untuk memperbaiki diri atau membuktikan diri bahwa mereka tidak sefaham dan bahkan tidak mendukung gerakan PKI. Namun kehidupan mereka baik dari aspek agama, sosial, dan politik tetap saja mendapat stigma dan stereotype yang tidak mengenakkan. Oleh karena itu, penelitian ini bertujuan untuk menganalisa fenomena kehidupan (keagamaan, sosial dan budaya) keturunan eks PKI yang berada di Kabupaten Banyuwangi.

\section{B. Landasan Teori}

\section{Kehidupan Agama}

Para pakar memiliki beragama pengertian tentang agama. Agama terdiri dari kata "a" (tidak), dan "gama" (kacau). Dengan demikian, agama adalah sejenis peraturan yang menghindarkan manusia dari kekacauan, serta mengantarkan menusia menuju keteraturan dan ketertiban.Konsep agama, dikenal pula dengan istilah religion (Bhs. Inggris), religio atau religi (Bhs. Latin), al-din (Bhs. Arab), 
dan dien (Bhs. Semit). Kata-kata itu diasumsikan memiliki kemiripan makna dengan kata "agama" yang berasal dari bahasa Sansekerta. Religious (Inggris) berarti kesalehan, ketakwaan, atau sesuatu yang sangat mendalam dan berlebihlebihan.

Religiusitas adalah kadar kualitas dan kuantitas seseorang dalam menjalankan agamanya (Fitriani, 2016:3). Agama adalah sebuah syariat, pedoman, dan tuntunan dalam menjalani kehidupan beragama. Sementara relegiusitas adalah konsepsi dan komitmen seseorang terhadap agamanya. Konsepsi terkait dengan pemahaman terhadap ajaran agama, sementara itu komitmen terkait dengan pengamalan ajaran agama tersebut dalam hubungan interpersonal antar sesama manusia maupun dengan Allah SWT. (Sari, 2012:312).

Religiusitas terdiri dari lima dimensi. a) Dimensi ideologi (Religious Belief/Ideological Dimension), berkaitan dengan harapan-harapan seseorang. b) Dimensi praktik ibadah (Religious Practice/Ritual Dimension) yang meliputi perilaku pemujaan dan pelaksanaan ritus keagamaan yang formal. c) Dimensi Pengalaman (Religious Feeling/Experiential Dimension), berkaitan dengan pengalaman keagamaan, perasaan, dan persepsi seseorang. d) Dimensi pengetahuan agama (Religious Knowledge/Intellectual Dimension) mengacu pada harapan seseorang yang beragama. e) Dimensi Konsekuensi (Religious Effect/Consequential Dimension) mengacu pada sejauh mana ajaran keyakinan yang dianut mempengaruhi perilakunya (Lindzey dan Aronson, 1975:20; Spilka, Hood dan Gorsuch, 1985:25).

Dimensi religius di atas, dipengaruhi oleh berbagai faktor:faktor sosial, alami, dan kebutuhan untuk mendapatkan harga diri, intelektual (Thouless, 2000:15), faktor internal, dan eksternal (Jalaluddin, 2012:12-13). Masih ada lagi faktor-faktor yang lain, yaitu: pertentangan batin atau konflik batin dan ketegangan perasaan; pengaruh hubungan dengan tradisi agama; ajakan dan sugesti; faktor-faktor emosi; dan faktor kemauan (Arifin, 2008:49 \& 76).

Terdapat hasil penelitian yang menunjukkan bahwa faktor keluarga dan kegiatan dakwah sangat berpengaruh terhadap keberagamaan seseorang (Alfiatin, 1998:62), fatwa tentang penistaan agama cenderung ikut memprovokasi kelompok keagamaan untuk berpandangan tertutup dan intoleran (Nurrohman; Heryana, 
Rudy dan Sahid, 2015:2), dan faktor keterbukaan melalui dialog (Ismail, 2010:175).

Dari paparan dan hasil penelitian terdahulu, dapat dipahami bahwa 5 (lima) dimensi religius di atas, dipengaruhi oleh 2 (dua) faktor utama, yaitu faktor internal dan faktor eksternal. Faktor internal meliputi: faktor alami (pengalaman), kebutuhan, intelektual, emosi, kemauan, dan konflik batin. Sedangkan faktor eksternal meliputi: faktor sosial, agama, ajakan dan sugesti.

\section{Kehidupan Sosial}

Ajaran agama selalu mengajarkan persamaan dan keadilan dalam segala aspek kehidupan (equality of low and life). Sebagai mahluk, manusia tidak pernah merequest akan keberadaannya di dunia. Terlahir dari orang tua siapapun, manusia tinggal menerima, sebagai sesuatu given dari-Nya. Dari etnis apa, dari suku bangsa apa, dari negara mana, dari partai politik apa, dan bahkan dari keyakinan agama apa (teisme -polytheisme dan monotheisme- atau ateisme), semua harus diterima. Semua itu adalah anugerah dan kehendak-Nya yang harus disyukuri dan dijalani berdasarkan rambu rambu hukum (god's or human law) dalam melaksanakan aktivitas sehari-hari, baik yang berdimensi vertikal maupun horizontal (Q.S. 49. (13) Q.S. 3 (112).

Dalam kehidupan bermasyarakat, berbangsa dan bernegara, persamaan dan keadilan itu diidentikkan dengan demokrasi. Demokrasi adalah government of the people, by thepeople, (and) for the people (Epstein, 2011:819). Di Indonesia, demokrasi yang digunakan adalah demokrasi Pancasila. Rakyat memang yang berkuasa, namun kekuasaan tersebut harus selaras dan sejalan dengan dasar negara Pancasila (Purnaweni, 2004:118).

Rakyat yang dimaksud dalam demokrasi (termasuk demokrasi Pancasila) adalah rakyat atau perwakilannya yang sedang menduduki jabatan di pemerintahan. Sebagai pejabat mereka harus melaksanakan amanahnya untuk kepentingan semua rakyat dengan berbagai latar belakang budaya, politik, kepercayaan, dan agama. Termasuk dalam hal ini adalah mereka yang berlatar belakang keturunan mereka yang pernah berafiliasi ke Partai Komunis Indonesia (PKI), yang kemudian lebih dikenal dengan sebutan eks PKI. 
Pembubaran PKI membawa dampak traumatic-psychologic bagi para mantan pendukung PKI dan keluarganya. Salah satu dampak yang paling mengemuka adalah diskriminasi perlakuan terhadap mereka-baik fisik maupun non-fisik) yang lazim disebut dengan istilah bullying atau persecute (bhs. Inggris, yang berarti penindasan, atau penganiayaan). Bullying is bullying is identified as a specific conduct of aggressive behavior (Benítez dan Fernando. 2006:153; Hemphil, Heerde dan Gomo, 2014:11). Perilaku bullying berdampak pada banyak kesempatan dan masa depanyang tidak dapat diakses oleh para eks PKI. Misalnya, kesempatan menjadi pejabat di pemerintahan, menjadi aparat sipil negara, maupun jabatan-jabatan publik dan sosial lainnya. Jika hal ini diberlakukan bagi para penggiat dan pendukung PKI, mungkin dapat dimaklumi, namun jika hal ini diberlakukan bagi keluarga atau anak cuku mereka yang tidak sama sekali sehaluan dan sefaham dengan orang tua mereka, maka hal ini dapat dipandang sebagai sebuah ketidak-adilan, dan sebuah diskriminasi di tengah demokrasi.

Sikap diskriminasi dan bullying ini tidak sejalan dengan kebutuhan dasar manusia. Manusia tidak hanya menginginkan terpenuhinya kebutuhan fisiologis, namun juga kebutuhan rasa aman dan perlindungan, kebutuhan rasa cinta, memiliki dan dimiliki, kebutuhan harga diri, dan bahkan kebutuhanaktualisasi diri (David, Frederick dan Alex, 2017:23).

Kebutuhan mendasar manusia menurut Abraham Maslow bergerak mulai dari yang paling rendah namum mendasar, hingga yang paling tinggi sebagai pretige diri. Suatu kebutuhan yang telah terpuaskan akan disusul oleh berbagai bentuk kebutuhan lain yang juga menuntut pemuasan. Ketidak pernah puas ini, sejatinya tidak hanya terjadi pada aspek pemenuhan kebutuhan yang sifatnya duniawi, namun juga kebutuhan yang bersifat ukhrowi(Q.S. 102 (1-2)). Namun tidak demikian dalam persoalan ukhrowiy. Seringkali manusia merasa puas terhadapnya, sekalipun masih memperoleh sedikit atau kecil. Padahal Tuhan AllahSwt. justru menyarankan agar dalam persoalan akhirat atau amal ibadah seseorang tidak pernah puas(Q.S.94 (7-8).

Dari sifat mendesak atau tidaknya, kebutuhan manusia dapat dibagi ke dalam dua kategori, yaitu kebutuhan mendasar (basic needs), dan kebutuhan berkembang (metaneeds). Kebutuhan mendasar terdiri dari 4 jenis kebutuhanm 
yaitu: a) kebutuhan fisiologis (fisik biologis, the physiological needs), b) kebutuhan rasa aman dan perlindungan (the safety needs), c) kebutuhan rasa cinta, memiliki dan dimiliki (the belonging needs), dan d) kebutuhan harga diri (theesteem needs). Sedangkan kebutuhan berkembang hanya terdiri dari satukebutuhan, yaitu kebutuhan aktualisasi diri (the need for self-actualization).

Setiap orang tentu menginginkan tercapainya kebutuhan aktualisasi diri dengan segala bentuk dan parameter masing masing. Ada sesorang yang merasa sudah mencapai kebutuhan aktualisasi diri, namun bagi orang lain kondisi tersebut boleh jadi masih dipandang sebagai kebutuhan harga diri. Begitulah realitasnya kebutuhan manusia itu bersifat relatif, sebagaimana relatifitasnya pandanganmanusia akan kondisi ketercapakain kebutuhan bagi orang lain. Itulah hukum alam atau sunnatullah yang menjadikan kondisi manusia senantiasa berbeda dalam kemampuan memenuhi kebutuhannya. Kondisi semacam ini sejatinya justru membawa hikmah agar manusia saling berinteraksi dan saling membantu karena satu sama lain saling membutuhkan (Ali dan Asrori 2004:87).

Konsep ini mengandung pengertian bahwa interaksi adalah suatu tindakan yang dilakukan oleh seseorang dan stimulus bagi tindakan individu lain yang menjadi pasangannya. Proses interaksi sosial yang terjadi secara tidak maksimal akan menyebabkan terjadinya kehidupan yang terasing, misalnya sengaja dikucilkan dari lingkungannya, mengalami cacat, pengaruh perbedaan ras dan perbedaan budaya.

Interaksi sosial dapat berbentuk asosiatif dan disasosiatif (Soekanto, 2010:64). Asosiatif terdiri atas kerjasama, dan akomodasi. Kerjasama disini dimaksudkan sebagai suatu usaha bersama antara orang perorangan atau kelompok manusia untuk mencapai satu atau beberapa tujuan bersama. Akomodasi merupakan suatu cara untuk menyelesaikan pertentangan tanpa menghancurkan pihak lawan sehingga lawan tidak kehilangan kepribadiannya.

Disasosiatif terdiri atas persaingan, dan kontravensi, serta pertentangan. Persaingan diartikan sebagai suatu proses sosial di mana individu atau kelompokkelompok manusia yang bersaing mencari keuntungan melalui bidang-bidang kehidupan yang pada suatu masa tertentu menjadi pusat perhatian umum (baik perseorangan maupun kelompok manusia) dengan cara menarik perhatian publik 
atau dengan mempertajam prasangka yang telah ada tanpa mempergunakan ancaman atau kekerasan.

Interaksi sosial adalah realitas dari perilaku sosial (yaitu suasana saling ketergantungan yang merupakan keharusan untuk menjamin keberadaan manusia).Sebagai bukti bahwa manusia dalam memenuhi kebutuhan hidupnya tidak dapat melakukannya sendiri melainkan memerlukan bantuan orang lain (Ibrahim, 2001:34). Ada ikatan saling ketergantungan diantara satu orang dengan yang lainnya. Artinya bahwa kelangsungan hidup manusia berlangsung dalam suasana saling mendukung dalam kebersamaan. Untuk itu manusia dituntut mampu bekerja sama, saling menghormati, tidak menggangu hak orang lain, toleran dalam hidup bermasyarakat (Ibrahim, 2014:35).

Bentuk dan perilaku sosial seseorang dapat pula ditunjukkan oleh sikap sosialnya (Azhari, 2004:161).Berbagai bentuk dan jenis sikap sosial pada dasarnya merupakan karakter atau ciri kepribadian yang dapat teramati ketika seseorang berinteraksi dengan orang lain. Seperti dalam kehidupan berkelompok, kecenderungan perilaku sosial seseorang yang menjadi anggota kelompok akan terlihat jelas diantara anggota kelompok lainnya. Perilaku sosial dapat dilihat melalui sifat-sifat dan pola respon antarpribadi, yaitu: kecenderungan perilaku peran, kecenderungan perilaku dalam hubungan sosial, dan kecenderungan perilaku ekspresif (Rikarahim dan Hidayat. 2015:165).

Terdapat sejumlah hasil penelitian yang menunjukkan bahwa dalam kehidupan sosial, manusia harus berupaya menyeimbangkan antara kepentingan individu dan kepentingan masyarakat (Maharani, 2016:50), manusia harus melakukan dan mempertahankan pola ikatan atau ashobiyah, baik karena nasab, atau karena faktor pekerjaan dan kepentingan lainnya (Sofiudin, 2015:78), dan memperkuat keyakinan terhadap nilai-nilai agama demi terciptanya perilaku sosial yang didasarkan atas rambu-rambu agama (Wahab, 2015:39).

Berdasarkan uraian dan hasil penelitian terdahulu, dapat dipahami bahwa perilaku sosial tidak dapat dipisahkan dari dukungan sosial, yaitu dukungan atau bantuan yang berasal dari orang lain seperti teman, tetangga, teman kerja dan orang- orang lainnya (Mahmudi dan Suroso. 2014:187). Dukungan yang diberikan 
seseorang dapat dipengaruhi oleh kebutuhan fisik, kebutuhan sosial, dan kebutuhan psikis (Baran dan Davis, 2010:45; Bart, 1994:136).

\section{Kehidupan Budaya}

Budaya adalah hasil cipta, rasa dan karsa manusia dalam memenuhi kebutuhan hidupnya yang mencakup pengetahuan, keyakinan, seni, susila, hukum adat, kecakapan, dan kebiasaan. Kebudayaan berasal dari bahasa Sanskerta Budhayah bentuk jamak dari kata budhi, yang berarti akal. Jadi, kebudayaan adalah hal-hal yang bersangkutan dengan akal (Nasution, Daulay, Susanti dan Syam, 2015:14). Budaya adalah rancangan hidup yang tercipta secara historis, baik yang tersurat, tersirat, rasional, maupun irasional yang ada pada suatu waktu sebagai pedoman bagi perilaku manusia.

Setiap kebudayaan memiliki 7 (tujuh) unsur kebudayaan universal: a) sistem religi dan upacara keagamaan, produk manusia sebagai homo religius; b) sistem organisasi kemasyarakatan, produk manusia sebagai homo socius; c) sistem pengetahuan, produk manusia sebagai homo sapiens, d) sistem mata pencaharian hidup, merupakan produk dari manusia sebagai homo economicus, e) sistem teknologi dan perlengkapan hidup manusia, produk manusia sebagai homo faber, f) bahasa, produk manusia sebagai homo languens, dan g) kesenian, produk manusia dalam keberadaannya sebagai homo esteticus (Siany dan B. Atiek. 2009:54).

Budaya memiliki orientasi nilai yang bersifat komplek tetapi terpola pada prinsip yang mengutamakan tatanan, tindakan dan pikiran tentang solusi dalam memecahkan masalah. Teori Orientasi Nilai Budaya dirintis oleh sepasang suami istri antropolog Clyde Kluckhohn dan Florence Kluckhohn yang diuraikan dalam serangkaian karangannya, kemudian dituangkan dalam karya mereka yang berjudul Variations in Value Orientation (Marzali, 2006:242). Menurut teori ini, minimal ada lima hal yang paling tinggi nilainya dalam setiap kebudayaan manusia: a) human nature atau makna hidup manusia; b) man nature atau makna dari hubungan manusia dengan alam sekitarnya, c) time atau persepsi manusia mengenai waktu, d) activity atau masalah makna dari pekerjaan, karya, dan amal dari perbuatan manusia, dan e) relational atau yaitu hubungan manusia dengan sesama manusia. 
Lima masalah inilah yang disebut value orientations atau orientasi nilai budaya. Hidup itu adalah sumber keprihatinan dan penderitaan maka kemungkinan variasi konsepsi nilai budayanya dirumuskan oleh Kluckhohn dengan kata evil. Sebaliknya, dalam banyak kebudayaan yang menganggap hidup itu adalah sumber kesenangan dan keindahan, dirumuskan dengan kata good.

Ada kebudayaan yang mengkonsepsikan alam sedemikian dahsyat dan sempurna sehingga manusia sepatutnya tunduk saja padanya (subjugation to nature). Namun, ada juga kebudayaan yang mengajarkan kepada warganya agar mampu menjajaki rahasia-rahasianya untuk menaklukkan dan memanfaatkan alam guna memenuhi kebutuhan (mastery over nature). Ada kebudayaan yang mementingkan masa sekarang (present), ada pula yang berorientasi masa depan (future). Ada kebudayaan yang mengajarkan sejak awal untuk hidup bergotongroyong (collaterality) serta menghargai terhadap perilaku pemuka-pemukanya sebagai acuan kebudayaan sendiri (lineality). Sebaliknya, ada pula kebudayaan yang menekankan hak individu untuk mandiri, maka orientasinya adalah mementingkan mutu dari karyanya, bukan atas senioritas kedudukan, pangkat, maupun status sosialnya. Berdasarkan paparan di atas, sejatinya seni atau karya seni dapat dijadikan sebagai sarana untuk berinteraksi dan menyampaikan pesanpesan moral (Rondhi, 2014:121), mengekspresikan ide-ide (Wiflihani, 2016:107), dan bahkan dapat berfungsi secra sosial dan ritual serta menjadi media yang mampu memfasilitasi doa dan harapan mereka (Irianto, 2017:98).

\section{Metode Penelitian}

Penelitian ini dilaksanakan dengan pendekatan kualitatif dengan jenis penelitian fenomenologi, dimana data-data yang didapatkan berupa data verbal, tulisan maupun perilaku yang unik dari orang-orang yang diteliti, yang berbeda dari kelompok masyarakat lainnya. Fenomena yang dimaksud dalam penelitian ini adalah fenomena kehidupan agama, sosial dan budaya para keturunan anggota eks PKI di Kabupaten Banyuwangi, khususnya kecamatan Rogojampi, Singojuruh, Cluring, dan Tegaldlimo.

Sumber data(subyek terteliti) dalam penelitian ini adalah para keturunan anggota eks PKI yang berada di Kabupaten Banyuwangi, tepatnya di kecamatan 
Singojuruh Rogojampi, Cluring, dan Tegaldlimo. Sumber data ini ditentukan dengan teknik purposive sampling. Mereka adalah para keturunan asli dari anggota eks PKI atau orang-orang terdekat dengan mereka. Informasi dapat diperoleh dari kantor kecamatan terkait, kelurahan/desa serta para tokok-tokoh masyarakat di lingkungan wilayah-wilayah tersebut.

Terdapat tiga metode pengumpulan data yang digunakan, yaitu wawancara, obervasi dan dokumentasi. Wawancara digunakan dengan menggunakan teknik semi-struktur wawancara. Instrumen pedoman wawancara dibuat berdasarkan variabel-variabel yang terdapat pada rumusan masalah, yaitu pertanyaanpertanyaan tentang kehidupan beragama, sosial dan budaya. Instrumen pedoman wawancara terlampir. Observasi digunakan mengetahui secara langsung kehidupan keturunan eks PKI sehari-hari di tengah tengah masyarakat. Dokumentasi digunakan untuk mengumpulkan data-data yang diperlukan sebagai penguat hasil observasi dan wawancara.

Teknik analisis data dalam penelitian ini menggunakan analisis data kualitatif model interaktif yang ditawarkan oleh Miles, Huberman, dan Saldana yang terdiri atas empat komponen, yaitu data collection, data condensation, data display, and conclusion drawing/verification (Miles, Humerman dan Saldana, 2014:33).

\section{Hasil}

Berdasarkan paparan dan analisis data yang dieroleh melalui wawancara, dikuatkan oleh hasil observasi dan dokumentasi, dapat dideskripsikan hasil penelitian sebagai berikut.

\section{Kehidupan beragama keturunan eks PKI di Kabupaten Banyuwangi}

Kehidupan beragama keturunan eks PKI di kabupaten Banyuwangi berjalan seperti para pemeluk agama lainnya. Mereka kebanyakan mengakui bahwa keterlibatan orang tua dan nenek kakek mereka ke dalam PKI hanyalah karena faktor ketidak mengertian dan faktor ekonomi. Mereka saat ini menjalankan agama mereka sesuai agama yang mereka peluk sebelum terlibat anggota PKI. Mayoritas mereka memeluk agama Islam, namun ada pula yang memeluk agama Kristen Protestan, Katolik, Hidun, Budha, dan bahkan Kejawen atau aliran 
kepercayaan. Para eks keturunan PKI di Banyuwangi memeluk agama sebagaimana agama yang dipeluk oleh orang tua mereka (sebelum terlibat dalam PKI).

\section{Kehidupan bersosial eks keturunan PKI di Kabupaten Banyuwangi}

Kehidupan bersosial eks keturunan PKI di kabupaten Banyuwangi berjalan normal, dalam artian saling asah, asih, dan asuh satu sama lain. Sementara dari aspek pekerjaan mereka banyak bekerja sebagai guru, petani atau swasta dan mengikuti program transmigrasi. Mereka diterima sebagai anggota masyarakat sebagaimana layaknya masyarakat non eks PKI. Namun ada juga yang berjalan tidak normal, masih mendapatkan perlakuan diskriminasi, masih dikucilkan, dan masih saja diberi label sebegai orang keturunan Partai Terlarang.Mereka menerima kenyataan ini sambil tetap berupaya mencari keadilan dan pembebasan dari stigma negatif dan streotype, agar mereka dapat menjalani kehidupan sosial yang normal sebagai anggota masyarakat sebagaimana layaknya masyarakat non eks PKI.

\section{Kehidupan budaya keturunan eks anggota PKI di Kabupaten Banyuwangi}

Kehidupan budaya keturunan eks anggota PKI di Banyuwangi tetap eksis dalam mengembangkan budaya dan kesenian, seperti Gandrung, Kuntulan, Hadrah, Wayang Orang (Prabuloro), Jaranan, dan Angklung.Seni bagi mereka adalah ekspresi dan kebebasan dalam menyampaikan ide melalui musik dan kesenian. Seni adalah sarana untuk bertemu, bertukar fikiran, dan berdiskusi dalam berbagai hal yang terkait dengan kehidupan. Topik diskusi muncul secara insidental, mulai dari topik rumah tangga, pekerjaan, kehidupan sehari-hari, hingga kehidupan berbangsa dan bernegara di Negara Kesatuan Republik Indonesia.

\section{E. Pembahasan}

\section{Kehidupan beragama keturunan eks PKI di Kabupaten Banyuwangi}

Kehidupan beragama keturunan eks PKI di kabupaten Banyuwangitidak jauh berbeda dengan para pemeluk agama lainnya. Mereka beragama seperti 
agama orang tua mereka. Mereka saat ini menjalankan agama mereka sesuai agama yang mereka peluk sebelum terlibat anggota PKI. Ada yang beragama Islam, Kristen Protestan, Katolik, Hidun, Budha, dan bahkan Kejawen atau aliran kepercayaan. Kualitas keagamaan mereka beragama, ada yang taat, ada pula yang formalitas. Mereka mayoritas mengakui bahwa keterlibatan mereka ke dalam PKI lebih disebabkan oleh faktor ekonomi dan faktor ketidak-tahuan.

Secara universal, manusia dengan latar multikulturalnya senantiasa memiliki keterkaitan dengan agama. Fenomena ini menunjukkan bahwa tidak ada sebuah masyarakat dunia yang tidak beragama (Amtrong, 1993:9). Jadi manusia senantiasa agamis, termasuk masyarakat Banyuwangi. Mereka meyakini bahwa agama memiliki banyak fungsi. Agama berfungsi sebagai petunjuk arah kehidupan bagi manusia agar memperoleh keselamatan dan kebahagiaan di dunia dan di akhirat. Agama mengajarkan tentang interaksi antar sesama manusia, antara manusia dengan lingkungan, dan bahkan dengan Tuhan dalam rangka membangun keselamatan, kedamaian dan kasih sayang (Mulkan, 2001:1).

\section{Kehidupan bersosial eks keturunan PKI di Kabupaten Banyuwangi}

Kehidupan bersosial eks keturunan PKI di kabupaten Banyuwangi berjalan normal, dalam artian saling asah, asih, dan asuh satu sama lain. Sementara dari aspek pekerjaan mereka banyak bekerja sebagai guru, petani atau swasta dan mengikuti program transmigrasi. Mereka diterima sebagai anggota masyarakat sebagaimana layaknya masyarakat non eks PKI, namun ada juga yang masih mendapatkan perlakuan diskriminasi, masih dikucilkan, dan masih saja diberi label sebegai orang keturunan Partai Terlarang. Mereka menerima kenyataan ini sambil tetap berupaya mencari keadilan dan pembebasan dari stigma negatif dan streotype, agar mereka dapat menjalani kehidupan sosial yang normal sebagai anggota masyarakat sebagaimana layaknya masyarakat non eks PKI.

Secara prinsipil, manusia ingin memenuhi kebutuhan hidupanya mulai dari 4 (empat) kebutuhan yang bersifat mendasar (basic needs) hingga 1 (satu) kebutuhan yang bersifat pelengkap (meta needs). Maslow memandang kebutuhan manusia itu tersusun dalam bentuk hirarki atau berjenjang. Setiap jenjang kebutuhan dapat dipenuhi hanya apabila jenjang sebelumnya telah (relatif) 
terpenuhi. Jenjang kebutuhan tersebut bersifat mengikat, maksudnya; kebutuhan pada tingkat yang lebih rendah harus relatif terpuaskan sebelum orang menyadari atau dimotivasi oleh kebutuhan yang jenjangnya lebih tinggi. Kebutuhan fisiologis harus terpuaskan lebih dahulu sebelum muncul kebutuhan rasa aman, baru kemudian muncul kebutuhan kasih sayang, hingga muncul kebutuhan meta (Rosaliza, 2017:94).

Lima kebutuhan manusia memang harus diperjuangkan, namun perlu didasari oleh kebaikan atau kemaslahatan bagi ummat manusia. Maslahat itu adalah segala bentuk perbuatan yang mengacu kepada terpeliharanya lima kebutuhan paling mendasar bagi manusia yaitu agama, jiwa akal, keturunan dan harta (Al-Ghazaly, 1983:286). Kelima hal yang harus dijaga ini menurut Imam Asy Syatibi disebut dengan dhururiyatul khomsah (lima hal yang harus dijaga: agama, jiwa, keturunan, akal, dan harta (Abubakar, 2012:85 dan Al-Syathiby, 1979:6).

Al Qur'an dalam Surat al-Mumtahanah (60:12), mengungkapkan tentang salah satu cara menjaga dhururiyatul khomsah (Susilawati. 2015:7). Ayat tersebut mengungkapkan bagaimana seseorang harus menjauhi sifat syirik (menjaga agama), tidak mencuri (memelihara harta seseorang), tidak berzina (memelihara keturunan dan kehormatan seseorang), dan tidak membunuh (memelihara jiwa orang lain) (Dahlan, 1996:1109). Jika hal ini dapat dilakukan, maka masyarakat secara individu dan secara kolektif akan mendapatkan kedamaian dan kebahagiaan.

\section{Kehidupan budaya keturunan eks anggota PKI di Kabupaten Banyuwangi}

Kehidupan budaya keturunan eks anggota PKI di Banyuwangi mereka eksis dalam mengembangkan budaya dan kesenian, seperti Gandrung, Kuntulan, Hadrah, Wayang Orang (Prabuloro), Jaranan, dan Angklung.Seni bagi mereka adalah ekspresi dan kebebasan dalam menyampaikan ide melalui musik dan kesenian. Istilah Budaya dan kebudayaan seringkali disamakan artinya sekalipun dapat pula dibedakan pengertiannya. Budaya memiliki makna sebagai cara hidup masyarakat yang selalu berkembang serta dimiliki oleh suatu kelompok manusia yang akan terus diturunkan atau diwariskan dari satu generasi ke generasi 
berikutnya. Budaya adalah sesuatu yang diturunkan secara genetis dari satu generasi ke generasi berikutnya.

Seni adalah sarana untuk bertemu, bertukar fikiran, dan berdiskusi dalam berbagai hal yang terkait dengan kehidupan. Topik diskusi muncul secara insidental, mulai dari topik rumah tangga, pekerjaan, kehidupan sehari-hari, hingga kehidupan berbangsa dan bernegara di Negara Kesatuan Republik Indonesia

Budaya terbentuk dari banyak unsur yang rumit, termasuk sistem agama dan politik, adat istiadat, bahasa, perkakas, pakaian, bangunan, dan karya seni.Dengan demikian budaya dapat diartikan sebagai hal-hal yang bersangkutan dengan akal dan cara hidup yang selalu berubah dan berkembang dari waktu ke waktu. Selain itu Kebudayaan memiliki beberapa wujud yang meliputi: Pertama wujud kebudayaan sebagai ide, gagasan, nilai, atau norma; Kedua wujud kebudayaan sebagai aktifitas atau pola tindakan manusia dalammasyarakat; Ketiga adalah wujud kebudayaan sebagai benda-benda hasil karya manusia. Wujud kebudayaan ini bersifat konkret karena merupakan bendabenda dari segala hasil ciptaan, karya, tindakan, aktivitas, atau perbuatan manusia dalam masyarakat. Perbedaan antara budaya dan kebudayaan adalah bahwa budaya itu merupakan cipta, rasa dan karsa suatu masyarakat, sedangkan kebudayaan merupakan hasil dari cipta, rasa dan karsa masyarakat tersebut (Koentjaraningrat, 2009:150-153).

Salah satu bentuk budaya atau kebudayaan adalah seni. Jika seni dihubungkan dengan kehidupan masyarakat, maka muncul dua pendapat terkait dengan fungsi yang diemban oleh seni. Pendapat pertama mengatakan bahwa seni diciptakan untuk membantu perkembangan kesadaran manusia, dan memajukan sistem sosial. Namun pendapat kedua mengatakan bahwa seni adalah berfungsi untuk dirinya sendiri, seni untuk seni. Namun nampaknya, pendapat pertama lebih banyak dikembangkan dengan tetap mempertahankan esensi seni yaitu estetika (nilai keindahan). Jika seni telah diubah fungsinya sebagai jembatan untuk mencapai sebuah tujuan di luar seni (sekalipun lebih mulia), maka itu berarti telah menurunkan martabat dan marwah penciptaan kreatif seni (Plekhanov. 2007:1). 
Agama, sosial, dan budaya, memiliki relasi yang kuat. Agama adalah pondasi dasar bagi seseorang dalam berinteraksi sosial dan berbudaya. Sebaliknya ritual keagamaan yang dilakukan, juga harus mempertimbangkan kondisi sosial dan budaya masyarakat setempat (Aziza, 2016:8). Meminjam bahasa Durkheim, agama merupakan fenomena sosial yang melekat dalam praktik sosial, jadi tidak hanya dalam bentuk kepercayaan, tetapi juga berfungsi dalam meningkatkan solidaritas sosial sekaligus sumber kesatuan moral (Kahmad, 2000:2).

Dengan demikian, kehidupan beragama senantiasa bersentuhan dengan realitas sosial dan budaya. Agama dalam relasi ini bahkan dipandang sebagai bagian dari budaya, sekalipun tetap menjaga otoritasnya sebagai syariat yang dijadikan dasar dan pegangan dalam kehidupan. Karena agama dapat pula dipandang dari sisi perilaku manusia saat berinteraksi dengan tuhan yang bersifat vertical-teosentris, maupun berinteraksi dengan sesama dan lingkungan yang bersifat moral-horizontal-antrposentris (Roibin, 2010:6).

\section{F. Kesimpulan}

Berdasarkan paparan dan analisis data, maka dapat diambil kesimpulan sebagai berikut. Pertama, kehidupan beragama ketunran eks PKI berjalan seperti para pemeluk agama lainnya. Mereka kebanyakan mengakui bahwa keterlibatan orang tua dan nenek kakek mereka ke dalam PKI hanyalah karena faktor ketidak mengertian dan karena faktor ekonomi. Mereka saat ini menjalankan agama mereka sesuai agama yang mereka peluk sebelum terlibat anggota PKI. Mayoritas mereka memeluk agama Islam, namun ada pula yang memeluk agama Kristen Protestan, Katolik, Hindu, Budha, dan bahkan kejawen atau aliran kepercayaan.

Kedua, kehidupan bersosial eks keturunan PKI di kabupaten Banyuwangi berjalan saling asah, asih, dan asuh. Sementara dari aspek pekerjaan mereka banyak bekerja sebagai guru, petani atau swasta dan mengikuti program transmigrasi. Mereka ada yang diterima sebagai anggota masyarakat sebagaimana layaknya masyarakat non eks PKI, namun ada juga yang diterima secara tidak atau kurang wajar, masih didiskriminasikan, masih dikucilkan, dan masih saja diberi label sebegai orang keturunan Partai Terlarang. 
Ketiga, kehidupan budaya keturunan eks anggota PKI di Kabupaten Banyuwangi mereka eksis dalam mengembangkan budaya dan kesenian Banyuwangi, seperti Ketoprak, Wayang Orang, Ludruk, Ande-Ande Lumut, Angklung, Kuntulan, dan Keroncong. Seni bagi mereka adalah ekspresi dan kebebasan dalam menyampaikan ide melalui musik dan kesenian.

Selanjutnya, berdasarkan kesimpulan di atas, dapat disampaikan saran saran atau rekomendasi sebagai berikut. Pertama, Pemerintah hendaknya tetap menjembatani terjadinya hubungan yang harmonis di tengah-tengah masyarakat tanpa melihat lagi latar belakang yang gelap di masa lalu. Mereka yang eks PKI dipandang sama dengan mereka yang bukan eks PKI.Kedua, masyarakat keturunan non-eks PKI hendaknya memandang bahwa keterlibatan mereka ke dalam PKI semata-mata bukan karena faktor kesengajaan, namun lebih dikarenakan faktor ketidak-pahaman dan faktor ekonomi atau pekerjaan.Ketiga, Masyarakat keturunan eks PKI hendaknya senantiasa berbenah diri dan senantiasa bersikap dan berpeliku positif dalam persoalan agama yang dianut, dalam bersosial di tengah-tengah masyarakat, dan berbudaya sesuai budaya yang ada di wilayah kabupaten Banyuwangi khususnya dan Indonesia umumnya.

\section{Daftar Pustaka}

Abubakar, Al Yasa'. 2012. Metode Istishlahiah Pemanfaatan Ilmu Pengetahuan Dalam Ushul Fiqh, Banda Aceh: CV Diandra Primamitra Media

Al-Ghazaly, Abu Hamid Muhammad bin Muhammad. 1983. Al-Mustashfa fi Ilm al- Ushul I, Beirut: Dar al-Kitab al-Ilmiyah

Alfiatin, Tina. 1998. Religiusitas Remaja: Stud1 Tentang Kehidupan Beragama Di Daerah Istimewa Yogyakarta. Artikel dalam Jurnal Psikologi, No. 1, Yogjakarta: Universitas Gadjah Mada

Ali, M. \& Asrori, 2004, M. Psikologi Remaja Perkembangan Peserta Didik. Jakarta: PT Bumi Aksara, .

Al-Syathiby, Abu Ishak, 1979. Al-Muwafaqat fi Ushul fi al-Syari'at, Beirut: Dar al-Ma'rifah

Amtrong, Karen, 2012. A History of God: The 4,000 Year Quest of Judiasm, Cristianity, and Islam. New York: Ballantine Books

Arifin, Bambang Syamsul. 2008. Psikologi Agama. Bandung: CV Pustaka Setia

Azhari. Akyas, 2004, Psikologi Umum dan Perkembangan, Jakarta Selatan: Penerbit Teraju

Aziza, Aulia. 2016. Relasi Agama dan Budaya. Artikel dalam jurnal Alhadharah, Vol. 15 No. 30. Juli-Desember 2016. Banjarmasin: IAIN Antasari 
Baran, Stanley. J dan Davis, K. Dennis, 2010. Teori Komunikasi Massa:Dasar, Pergolakan, dan Masa Depan, Jakarta: Salemba Humanika

Bart, Smet. 1994.Psikologi Kesehatan. (Jakarta: PT. Gramedia Widiasarna Indonesia

Benítez, Juan Luís \& Justicia, Fernando. 2014. Bullying: description and analysis ofthe phenomenon. Artikel dalam Electronic Journal of Research in Educational Psychology. No 9. Vol 4 (2), 2006. ISSN: 1696-2095. pp: 151-170, Dept. of Developmental and Educational Psychology, University of Granada.

Benítez, Juan Luís \& Justicia, Fernando. 2006. Bullying: description and analysis ofthe phenomenon. Artikel dalam Electronic Journal of Research in Educational Psychology. No 9. Vol 4 (2), 2006. ISSN: 1696-2095. pp: 151-170, Dept. of Developmental and Educational Psychology, University of Granada

Dahlan, Abdul Aziz (ed), 1996. Ensiklopedi Hukum Islam, Jakarta: Ichtiar Baru Van Hoeve

David O. Yawson, Frederick A. Armah \& Alex N.M. Pappoe. 2017. Enabling Sustainability: Hierarchical Need-Based Frameworkfor Promoting Sustainable Data Infrastructure in Developing Countries. Artikel dalam Sustainability ISSN 2071-1050 www.mdpi.com/journal/sustainability (online) Jumat, 6 Oktober 2017

Epstein, Richard A. 2011. Direct Democracy: Government Of The People, By The People, And For The People? Artikel dalam Harvard Journal of Law \& Public Policy. 2011. Vol. 34. University of Chicago Law School Chicago Unbound

Fitriani, Annisa. 2016. Peran Religiusitas Dalam Meningkatkan Psychological Well Being. Artikel dalam Al-AdYaN/Vol.XI, No.1/Januari-Juni/2016 Lampung: UIN Raden Intan.

Hemphill, S.A.; Heerde, J.A. and Gomo, R. 2014. Defining Bullying: A Conceptual Definition of School-Based Bullying for the Australian Research and Academic Community. Australia: Australian Research Alliance for Children and Youth Limited.

Ibrahim. Rusli, 2014, Landasan Psikologi Pendidikan Jasmani di Sekolah Dasar. Jakarta: Departemen Pendidikan Nasional.

Irianto, Agus Maladi. 2017. Kesenian Tradisional Sebagai Sarana Strategi Kebudayaan di Tengah Determinasi Teknologi Komunikasi. Artikel dalam NUSA, Vol. 12. No. 1 Februari 2017. Semarang: Universitas Diponegoro

Ismail, Arifuddin. 2010. Refleksi Pola Kerukunan Umat Beragama (Fenomena Keagamaan di Jawa Tengah, Bali dan Kalimantan Barat). Artikel dalam jurnal “Analisa” Volume XVII, No. 02, Juli - Desember 2010

Jalaluddin. 2012, Psikologi Agama, Jakarta Utara: Rajagrafindo Persada.

Kahmad, Dadang. 2000. Sosiologi Agama, Bandung: Remaja Rosda Karya

Kholis, Nur. 2012, Pernyataan Komnas Ham tentang Hasil Penyelidikan Pelanggaran HAM yang berat Peristiwa 1965 - 1966, dalam Majalah SUAR: Warkat Warta No. 1 Tahun . Menteng Jakarta, Komnas Ham.

Koentjaraningrat. 2009. Pengantar Ilmu Antropologi. Jakarta: RinekaCipta 
Kontras. 2012, Menyusun Puzzle Pelanggaran HAM 1965: Sebuah Upaya Pendokumentasian, Jakarta: Kontras.

Lindzey, G \& Aronson, E. (Eds). 1975, The Handbook of Social Psychology. New Delhi: Addison-Westly Publising Company

Maharani, Septiana Dwiputri. 2016. Manusia sebagai Homo Economicus: Refleksi atas Kasus-Kasus Kejahatan di Indonesia. Artikel dalam Jurnal Filsafat, Vol. 26, No. 1, Februari 2016. Yogyakarta: Universitas Gadjah Mada

Mahmudi, Moh. Hadi \& Suroso. Efikasi Diri, 2014, Dukungan Sosial dan Penyesuaian Diri dalam Belajar. Artikel dalam Jurnal Persona, Jurnal Psikologi Indonesia. Mei 2014, Vol. 3, No. 02. Surabaya: UNTAG.

Marzali. Amri, 2006, Pergeseran Orientasi Nilai Kultural dan Keagamaan di Indonesia: Sebuah Esai dalam Rangka Mengenang Almarhum Prof. Koentjaraningrat. Artikel dalam Jurnal Antropologi Indonesia. Vol. 30, No. 3, Jakarta: UI.

Maslow, Abraham, H. 1970. A Theory of Human Motivation dalam buku Motivation and Personality. New York: Harper \& Row,Publishers, Inc

Maslow, Abraham, H1954. Motivation and PersonalityThird Edition. New York: Harper \& Row,Publishers, Inc.

Miles, Matthew B.; Huberman, A. Michael \& Saldaña, Johnny. 2014. Qualitative Data Analysis: A Methods Sourcebook Third Edition. Arizona: State University

Mulkan, Abdul Munir. 2001. Dilema Manusia Dengan Diri dan Tuhan, Kata Pengantar dalam Th. Sumartana (ed). 2001. Pluralis, Konflik dan Pendidikan Agama di Indonesia, Yogjakarta: Pustaka Pelajar

Nasution, Syukri Albani; Daulay, Muhammad Nur Huein; Susanti, M.Neila \& Syam, .Syafruddin, 2015,Ilmu Sosial Budaya Dasar. Jakarta: PT RajaGrafindo Persada.

Nurrohman; Heryana, Rudy \& Sahid, Asep Abdul. 2015. Kebijakan Pemerintah Indonesia Dalam Bidang Agama dan Implikasinya terhadap Toleransi Kehidupan Beragama di Jawa Barat. Bandung: LPPM UIN Sunan Gunung Djati Bandung

Plekhanov. 2007. Art and Social Life. (Moscow: Foreign Languages Publishing House, 1957). Diterjemahkan ke dalam Bahasa Indonesia oleh Samandjaja dengan judul: Seni dan Kehidupan Sosial.Dey's Renaissance

Purnaweni, Hartuti, 2004, Demokrasi Indonesia: Dari Masa Ke Masa. Artikel dalam Jurnal Administrasi Publik, Vol. 3, No. 2, Semarang: FISIP, Universitas Diponegoro.

Rikarahim \& Hidayat, Muh. Yusuf. 2015, Perbandingan Perilaku Sosial Melalui Model Pembelajaran Group Investigation dan Think Pair Share Siswa Mata Pelajaran Fisika Kelas X SMA Negeri 1 Soromandi Kab. Bima. Artikel dalam Jurnal Pendidikan Fisika Vol. 3 No. 2, September 2015, ISSN 2355-5785. Makasar: UIN Alaudin.

Roibin. 2010. Agama dan Budaya: Relasi Konfrontatif atau Kompromistik. Artikel dalam Jurnal Hukum dan Syariah, Vol. 1 No. 1. Malang: UIN Maliki Malang 
Rondhi, Mohammad. 2014. Fungsi Seni bagi Kehidupan Manusia: Kajian Teoretik. Artikel dalam Jurnal Seni Imajinasi, Vol. VIII No. 2 Juli 2014. Semarang: Universitas Negeri Semarang

Rosaliza, Mita. 2017. Lapisan Sosial Masyarakat Perkotaan. Artikel dalam Jurnal Ilmu Budaya, Vol. 13, No. 2 Februari Tahun 2017. Pekanbaru: Universitas Riau

Sari, Yunita. 2012, Religiuisitas Pada Hijabers Community Bandung. Prosiding Seminar Nasional Penelitian dan PKM: Sosial, Ekonomi dan Humaniora, Bandung: Unisba.

Siany, Liestyasaari \& B. Atiek Catur. 2009, Khasanah Antropologi 1. Jakarta: Pusat Perbukuan Departemen Pendidikan Nasional.

Soekanto, Soerjono, 2010, Sosiologi Suatu Pengantar (Jakarta: PT. RajaGrafindo Persada

Sofiudin, Muh. 2015. Pandangan Ibnu Khaldun tentang Manusia dan Masyarakat (Skripsi). Yogyakarta: UIN Sunan Kalijaga

Spilka, B., Hood. R.W. \& Gorsuch, R.L. 1985. The Psychology of Religion: an Empirical Approach. Englewood Cliffs. New Jersey: Prentice-Hall, Inc.

Susilawati, Nilda. 2015. Stratifikasi Al-Maqasid Al-Khamsah Dan Penerapannya Dalam Al-Dharuriyat, Al-Hajjiyat, Al-Tahsiniyyat. Artikel dalam Jurnal MIZANI VOL. IX, NO.1, Februari 2015. Bengkulu: IAIN Bengkulu

Syamsul Arifin, Bambang 2008, Psikologi Agama, Bandung: CV Pustaka Setia.

Thouless, R. H. 2000, Pengantar Psikologi Agama. Alih Bahasa oleh Machnun Husein, Jakarta: Raja Grafindo Persada.

Wahab, Abdul Jamil (ed.). 2015. Indeks Kesalehan Sosial Masyarakat Indonesia. Jakarta: Kementerian Agama RI, Badan Litbang dan Diklat Puslitbang Kehidupan Keagamaan

Wiflihani. Fungsi Seni Musik dalam Kehidupan Manusia. Artikel dalam Anthropos: Jurnal Antropologi Sosial dan Budaya 2 (1) (2016): 101-107. Medan: Universitas Negeri Medan

Yuliarto dan Prajarto. 2005. Hak Asasi Manusia (HAM) di Indonesia: Menuju Democratic Governance. Jurnal Ilmu Sosial dan Ilmu Politik Vol 8 No 3. Maret 2005. Yogjakarta: Universitas Gajah Mada. 